\title{
ROOT-KNOT AND LESION NEMATODES IN COFFEE SEEDLINGS PRODUCED IN THE STATE OF MINAS GERAIS, BRAZIL
}

\author{
Willian César Terra ${ }^{1}$, Júlio Carlos Pereira da Silva², Vicente Paulo Campos ${ }^{3}$, \\ Sônia Maria de Lima Salgado ${ }^{4}$
}

(Received: May 26, 2017; accepted: October 16, 2017)

\begin{abstract}
Understanding the mechanisms of plant-parasitic nematodes (PPN) dispersion is vital to improve control strategies aiming to restrict dissemination of these plant parasites. In the present work, we evaluated the presence of PPN in Arabic coffee (Coffea arabica) seedlings produced in commercial nurseries in Minas Gerais, state, Brazil. A total of 2830 samples obtained from 318 coffee nurseries, in 84 counties within the South and Zona da Mata regions in Minas Gerais, Brazil and representing more than 62 million coffee seedlings, were analyzed. Meloidogyne spp. was identified in 11 samples from four counties. Pratylenchus spp. and Rotylenchulus reniformis were detected in 281 and 47 samples, respectively. According to the Regulatory Instruction $\mathrm{N}^{\circ} 35$ from the Ministry of Agriculture, Livestock and Food Supply (MAPA), in Brazil, coffee seedlings infected by Meloidogyne spp. are prohibited for commercialization and/or planting. However, such restrictions do not apply to other PPN. Therefore, seedlings sold in Minas Gerais may constitute sources of dissemination for root-lesion nematodes (Pratylenchus spp.) and the reniform nematode (R. reniformis).
\end{abstract}

Index terms: Coffea arabica, Meloidogyne spp., Pratylenchus spp., Seedlings.

\section{NEMATOIDE DE GALHAS E DAS LESÕES RADICULARES EM MUDAS DE CAFÉ PRODUZIDAS NO ESTADO DE MINAS GERAIS}

RESUMO: O entendimento dos mecanismos de dispersão dos fitonematoides é fundamental para o desenvolvimento de estratégias visando restringir a sua disseminação. No presente trabalho foi avaliada a presença de fitonematoides em mudas de café arábica (Coffea arabica) produzidas em viveiros comerciais no estado de Minas Gerais. Foram analisadas 2830 amostras, enviadas de 318 viveiros, localizados em 84 municípios, das regiões Sul e Zona da Mata, representando um total de mais 62 milhões de mudas. Meloidogyne spp. foi identificado em 11 amostras, enviadas de quatro municípios. A presença Pratylenchus spp. e Rotylenchulus reniformes foi constatada em, 281 e 47 amostras, respectivamente. Segundo a instrução normativa $\mathrm{N}^{\circ}$ 35 do Ministério de Agricultura, Pecuária e Abastecimento (MAPA), mudas de café infectadas com Meloidogyne spp. são impedidas de comercialização e plantio. No entanto, tais restrições não se aplicam a outros fitonematoides. Portanto, as mudas comercializadas em Minas Gerais podem atuar como em agentes disseminadores dos nematoides das lesões (Pratylenchus spp.) e do nematoide reniforme ( $R$. reniformes).

Termos para indexação: Coffea arabica, Meloidogyne spp., Pratylenchus spp., mudas.

\section{INTRODUCTION}

In 2016, the gross revenue of Brazilian coffee production was estimated in US\$ 7.62 billion (CONSÓRCIO PESQUISA CAFÉ 2016). In the state of Minas Gerais, accountable for more than $70 \%$ of the nations' production of Arabic coffee (CONAB, 2016), coffee plantations generates jobs and preserves workforce in rural areas (SANTOS et al., 2009).

Plant-parasitic nematodes (PPN) are considered a limiting factor for coffee production (CAMPOS; VILLAIN, 2005; CARNEIRO et al., 2008). In Brazil, coffee producers have coexisted with these parasites since the end of the $19^{\text {th }}$ century (GOELDI, 1887). Since then, the devastating effects of diseases caused by them have been reported in all production areas of the country (CASTRO et al., 2008; REZENDE et al., 2013; SALGADO et al., 2015).

Root-knot nematodes (Meloidogyne spp.), particularly Meloidogyne exigua, Meloidogyne paranaensis and Meloidogyne incognita, are the most important species for coffee crops in Brazil due to their destructive potential. Coffee plants infested by M. exigua are usually able to sustain a reasonable production; however, up to $45 \%$ yield losses may occur (BARBOSA et al., 2004a 2004b; BARBOSA; SOUZA; VIEIRA, 2010; MUNIZ et al., 2008). Parasitism by $M$. incognita and $M$. paranaensis produces more drastic symptoms, causing death of severe infested plantation and making planting of susceptible crops on infested areas an anti-economic activity (BOISSEAU et al., 2009; SHIGUEOKA et al., 2016).

\footnotetext{
1,4Empresa de Pesquisa Agropecuária de Minas Gerais/URESM - Campus UFLA - Cx. P. 176 - 37.200.000 - Lavras - MG wcterra@yahoo.com.br, soniaepamig@gmail.com

${ }^{2,3}$ Universidade Federal de Lavras/UFLA - Departamento de Fitopatologia/DFP - Cx. P. 3037 - 37.200-000 - Lavras - MG julioufla@yahoo.com.br, vpcampos@dfp.ufla.br
} 
Another group of nematodes frequently found in coffee areas are the root-lesion nematodes (CASTRO et al., 2008; KUBO; EULALIO; OLIVEIRA, 2015) from the genus Pratylenchus spp. In India and Indonesia, Pratylenchus coffeae is the most destructive PPN in coffee crops (WIRYADIPUTRA; TRAN, 2008). In Central America this species is also harmful (VILLAIN; HERNÁNDEZ; ANZUETO, 2008), while in Brazil reports of coffee crops being anti-economic due to the incidence of this species are unusual (MOURA, PEDROSA, PRADO, 2002). The reniform nematode, Rotylenchulus reniformis, is also a frequently reported species in Brazilian coffee crops (BARROS et al., 2014; CASTRO et al., 2008), however, without any references about its effect.

In the southern region of Minas Gerais state, accountable for more than $54 \%$ of the coffee production in the state (CONAB, 2016), the presence of $M$. paranaensis and $M$. incognita in coffee crops was not verified after a broad survey performed in 2008 (CASTRO et al., 2008). However, during the last nine years, $M$. paranaensis was identified in plantations in five counties within this region (Alpinópolis, Coqueiral, Três Pontas) (SALGADO et al., 2015), Carmo do Rio Claro and Carmo de Cachoeira. In such plantations, the presence of this nematode caused severe damages. Thus, it urges to know and understand the factors that have contributed to disseminate this nematode in coffee crops within the main producing region in the country.

Use of coffee seedlings infected with nematodes is the main and more efficient form of dissemination for these microorganisms. During the 70 's the employment of coffee seedlings infected with $M$. incognita produced in the state of Parana, was responsible for the introduction of this nematode in several non-infested areas in the state of Sao Paulo (Ferraz, 2008). In 1976/1977, approximately 3.3 million infected coffee seedlings were discarded only in the state of Sao Paulo (FERRAZ, 2008).

Planting seedlings free from pathogens is imperative to stablish perennial crops, thus, the definition of phytosanitary standards for nematodes in coffee seedlings is primordial. Policies and standards for production and commercialization of coffee (Coffea arabica L. and Coffea canephora Pierre ex A. Froehner) propagation's material were established by the Ministry of Agriculture, Livestock and Supply (MAPA), through the Regulatory Instruction (IN $35)$ in November $29^{\text {th }} 2012$.
Despite the improvements occurred in the last decades concerning the awareness of growers and extension workers about the importance of PPN; dissemination of extremely harmful species for coffee crops such as M. paranaensis is still increasing in Brazil. Besides that, until now, there is no broad survey of nematodes in coffee seedlings traded in the state of Minas Gerais. Thus, the present work had the objective to verify the phytosanitary status of coffee seedlings regarding the most harmful phytonematodes in coffee crops.

\section{MATERIALS AND METHODS}

\subsection{Analysis of samples}

According to the Regulatory Instruction IN 35 from MAPA, in order to perform nematological analyses the laboratory must be registered in the National Network of Agricultural Laboratories of the Unified System of Agricultural Health Service, affiliated to the National Registry of Seeds and Seedlings (RENASEM).

Samples were received at the Laboratory of Nematology from the Federal University of Lavras and were initially evaluated regarding to the number of seedlings sampled per plot. Samples in divergence with IN 35 standards were not analyzed. Correctly sampled trials were visually checked for root-knots. Once root-knots were identified they were detached to be dissected under stereo microscope where females of Meloidogyne spp. were evaluated. The remaining roots were placed in a blender with $200 \mathrm{ml}$ water and milled for 20 seconds. Then, the resulting material was sieved with a $425 \mu \mathrm{m}$ sieve attached over a $38 \mu \mathrm{m}$ sieve. The material retained in the $38 \mu \mathrm{m}$ sieve was then collected and centrifuged. Then, the supernatant was observed under light microscope in order to evaluate the presence of juveniles of Meloidogyne spp., adults of Pratylenchus spp. and females of $R$. reniformis.

During a four months period (October 2016 to January 2017) 2830 samples were analyzed. All samples were tested for presence of Meloidogyne spp., however, the presence of $R$. reniformes and Pratylenchus spp. was evaluated in 2414 samples. Samples were received form 84 counties, being 83 counties from the state of Minas Gerais (59regions South and Central West, 23 - Zona da Mata and Vale do Rio Doce and one from the Triângulo Mineiro) and one from the state of São Paulo. In relation to nurseries, 318 sent samples (251 South and Central West, 65 - Zona da Mata and Vale do Rio Doce, one from the Triângulo Mineiro and one from the state of São Paulo) (Figure 1). Samples received represented a total of 62.781 .899 seedlings from 31 cultivars of $C$. arabica. 


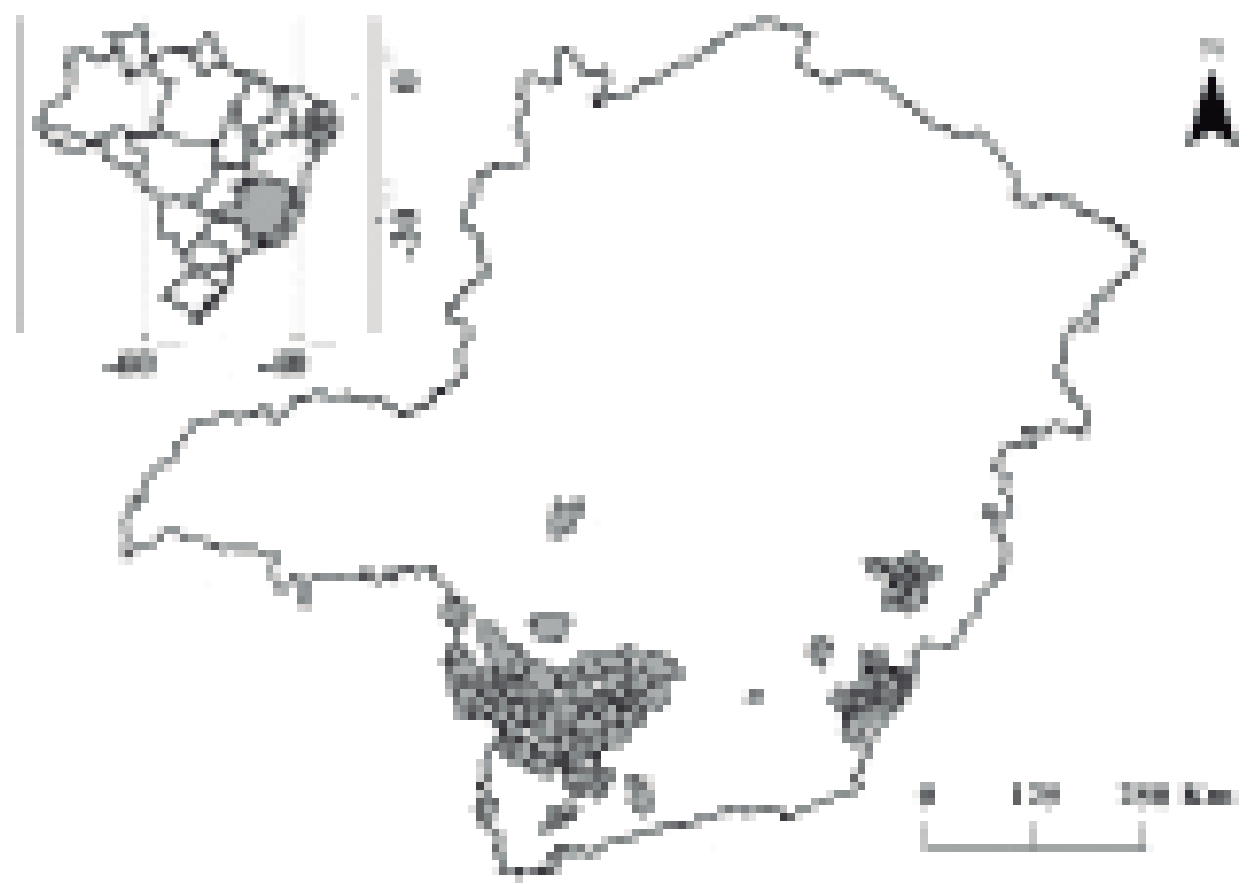

FIGURE 1 - Map of the Minas Gerais state. Highlighted counties that sent samples

\section{RESULTS AND DISCUSSION}

The presence of Meloidogyne spp. was observed in 11 samples obtained from four nurseries in the county of Rosário da Limeira, Muriaé, Carangola and Cabo Verde (Table 1). In these nurseries plants from the cultivars Catuaí Vermelho IAC 44 and Paraíso MG 2 were infected. Unfortunately, due to the great number of samples analyzed and the availability of a short period of time to release the technical report, it was not possible to identify Meloidogyne and Pratylenchus to the species level. Presence of root-knot nematodes (Meloidogyne spp.) in coffee plantations results in low productivity, ineffectiveness of soil fertilization, predisposition to parasitism by soil fungi, higher sensitivity to water stress and reduction of prices of agricultural lands (CAMPOS; VILLAIN, 2005; PEREIRA et al., 2012; SALGADO; REZENDE; CAMPOS 2005). Nevertheless, production of coffee seedlings infected by root-knot nematodes has being going on for decades in Brazil (FERRAZ, 2008). In this study, the presence of Meloidogyne spp., in 11 samples, proves the risk of dissemination of these PPN through seedlings is still imminent. Thus, surveillance of state agencies over coffee seedlings' trade avoid dissemination of root-knot nematodes.
The presence of Pratylenchus spp. was verified in 281 samples, representing $11.6 \%$ of the total evaluated samples. The root-lesion nematode was found in samples sent from 39 counties in ten coffee cultivars (Table 1 and Figure 2), however, with a low population density in the samples, mostly lower than 10 specimens per sample. The higher value found was of 38 specimens in a sample.

In India and Indonesia, $P$. coffeae is the most destructive PPN in coffee crops (WIRYADIPUTRA; TRAN, 2008). In Central America lesion nematodes are widely distributed and causeseverelosses(VILLAIN; HERNANDEZ; ANZUETO, 2008). In Brazil, despite being a common group of PPN, their influence on coffee plantations has yet to be determined, even though there are reports of the damaging potential of this group of nematodes in coffee seedlings (KUBO et al., 2003; TOMAZINI et al., 2005). Inomoto et al. (2007), suggested that some populations of Pratylenchus spp. are highly pathogenic to coffee plants in Brazil, causing damages even when in low population densities. Nevertheless, there are few records of unproductive coffee plantations due to the incidence of these nematodes (MOURA, PEDROSA, PRADO, 2002). 
TABLE 1 - Counties, number of samples and nurseries investigated as incidence of Meloidogyne spp., Pratylenchus spp. e Rotylenchulus reniformes.

\begin{tabular}{|c|c|c|c|c|c|}
\hline Counties & Nof samples & Nof nurseries & Meloidogyne spp & Pratylenchus spp & R. reniformis \\
\hline Alfenas & 8 & 1 & & & \\
\hline Alpinópolis & 8 & 2 & & $\mathrm{X}$ & \\
\hline Alterosa & 26 & 4 & & $\mathrm{x}$ & $\mathrm{X}$ \\
\hline Andradas & 20 & 1 & & $\mathrm{X}$ & \\
\hline Areado & 32 & 1 & & & \\
\hline Baependi & 12 & 1 & & $\mathrm{X}$ & \\
\hline Boa Esperança & 84 & 12 & & $\mathrm{x}$ & $\mathrm{X}$ \\
\hline Bom Jesus da Penha & 4 & 1 & & & \\
\hline Bom Sucesso & 32 & 2 & & $\mathrm{X}$ & \\
\hline Botelhos & 60 & 7 & & $\mathrm{X}$ & \\
\hline Cabo Verde & 44 & 6 & $\mathrm{x}$ & $\mathrm{X}$ & \\
\hline Cachoeira de Minas & 12 & 1 & & & \\
\hline Caiana & 8 & 1 & & $\mathrm{X}$ & \\
\hline Camacho & 8 & 1 & & & \\
\hline Cambuquira & 24 & 2 & & $\mathrm{X}$ & \\
\hline Campanha & 8 & 1 & & & \\
\hline Campestre & 32 & 7 & & $\mathrm{x}$ & $\mathrm{X}$ \\
\hline Campo Belo & 28 & 2 & & & $\mathrm{X}$ \\
\hline Campos Gerais & 64 & 10 & & & \\
\hline Candeias & 56 & 7 & & $\mathrm{x}$ & $\mathrm{X}$ \\
\hline Caparaó & 8 & 1 & & & \\
\hline Capela Nova & 4 & 1 & & & \\
\hline Carangola & 20 & 2 & $\mathrm{x}$ & & \\
\hline Carantiga & 16 & 2 & & & \\
\hline Carmo da Cachoeira & 20 & 2 & & $\mathrm{x}$ & $X$ \\
\hline Carmo do Rio Claro & 16 & 4 & & $\mathrm{x}$ & \\
\hline Carvalhópolis & 24 & 4 & & & $\mathrm{X}$ \\
\hline $\begin{array}{l}\text { Conceição da } \\
\text { Aparecida }\end{array}$ & 20 & 3 & & $\mathrm{x}$ & $\mathrm{X}$ \\
\hline Coqueiral & 56 & 5 & & $\mathrm{x}$ & \\
\hline Cordislândia & 12 & 1 & & $\mathrm{X}$ & \\
\hline Cristais & 32 & 4 & & $\mathrm{x}$ & $X$ \\
\hline Divino & 140 & 15 & & $\mathrm{x}$ & $\mathrm{X}$ \\
\hline Elói Mendes & 12 & 2 & & & \\
\hline Ervalia & 12 & 2 & & & \\
\hline Espera Feliz & 72 & 7 & & & \\
\hline Espírito Santo do & 20 & 1 & & & \\
\hline Pinhal (SP) & & & & & \\
\hline Fervedouro & 64 & 10 & & $\mathrm{X}$ & \\
\hline Guaranésia & 4 & 1 & & & \\
\hline Guaxupé & 128 & 11 & & $\mathrm{X}$ & $\mathrm{X}$ \\
\hline Heliodora & 12 & 3 & & $\mathrm{X}$ & \\
\hline Ibiraci & 72 & 6 & & $X$ & \\
\hline Ilicínea & 28 & 3 & & $\mathrm{x}$ & $\mathrm{X}$ \\
\hline Imbé de Minas & 4 & 1 & & & \\
\hline Inhapim & 4 & 1 & & & \\
\hline
\end{tabular}




\begin{tabular}{|c|c|c|c|c|c|}
\hline Itamogi & 52 & 6 & & $\mathrm{x}$ & \\
\hline Jacuí & 24 & 3 & & $\mathrm{x}$ & \\
\hline Jacutinga & 100 & 8 & & $\mathrm{X}$ & \\
\hline Jesuânia & 32 & 5 & & & \\
\hline Juruaia & 16 & 2 & & $\mathrm{x}$ & \\
\hline Lavras & 12 & 2 & & & \\
\hline Machado & 164 & 17 & & $\mathrm{x}$ & $\mathrm{X}$ \\
\hline Miradouro & 4 & 1 & & & \\
\hline Monte Belo & 12 & 2 & & $\mathrm{x}$ & \\
\hline Monte Santo de Minas & 36 & 4 & & & \\
\hline Muriaé & 4 & 1 & & & \\
\hline Muzambinho & 84 & 9 & & & \\
\hline Nepomuceno & 88 & 13 & & & \\
\hline Nova Resende & 72 & 8 & & & \\
\hline Oliveira & 60 & 5 & & & \\
\hline Orizania & 8 & 1 & & & \\
\hline Paraguaçu & 16 & 2 & & & \\
\hline Passos & 16 & 2 & & & \\
\hline Pedra Bonita & 24 & 2 & & $\mathrm{x}$ & \\
\hline Perdões & 16 & 1 & & & \\
\hline Piumhi & 96 & 5 & & & \\
\hline Poço Fundo & 28 & 4 & & & \\
\hline Ponte Nova & 4 & 1 & & & \\
\hline Rosário da Limeira & 20 & 4 & $\mathrm{x}$ & $\mathrm{x}$ & \\
\hline Santa Margarida & 8 & 2 & & & \\
\hline Santa Rita do Sapucaí & 20 & 2 & & & \\
\hline $\begin{array}{l}\text { Santo Antônio do } \\
\text { Amparo }\end{array}$ & 28 & 2 & & & \\
\hline $\begin{array}{l}\text { São Domingos das } \\
\text { Dores }\end{array}$ & 8 & 2 & & & \\
\hline $\begin{array}{l}\text { São Francisco do } \\
\text { Glória }\end{array}$ & 8 & 1 & & & \\
\hline $\begin{array}{l}\text { São Gonçalo do } \\
\text { Sapucaí }\end{array}$ & 12 & 1 & & & \\
\hline São Gotardo & 4 & 1 & & $\mathrm{X}$ & \\
\hline São Pedro da União & 12 & 1 & & & \\
\hline São Sebastião da Anta & 12 & 1 & & & \\
\hline $\begin{array}{l}\text { São Sebastião do } \\
\text { Paraíso }\end{array}$ & 32 & 3 & & $\mathrm{x}$ & $\mathrm{X}$ \\
\hline São Tomás de Aquino & 16 & 1 & & & \\
\hline Tombos & 4 & 1 & & & \\
\hline Três Pontas & 260 & 22 & & $\mathrm{x}$ & \\
\hline Ubaporanga & 16 & 4 & & & \\
\hline Varginha & 16 & 2 & & & \\
\hline Vieiras & 16 & 2 & & & \\
\hline
\end{tabular}


A

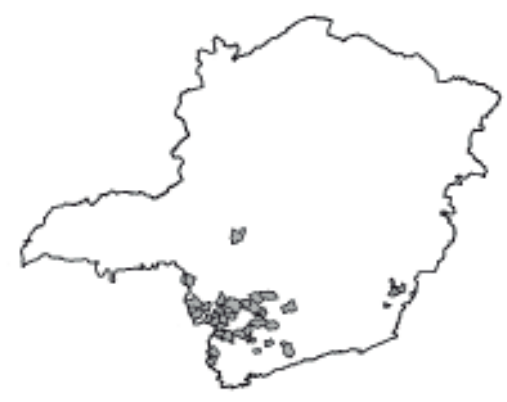

B

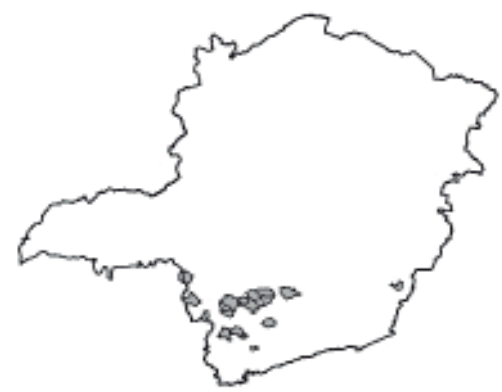

$\mathrm{C}$

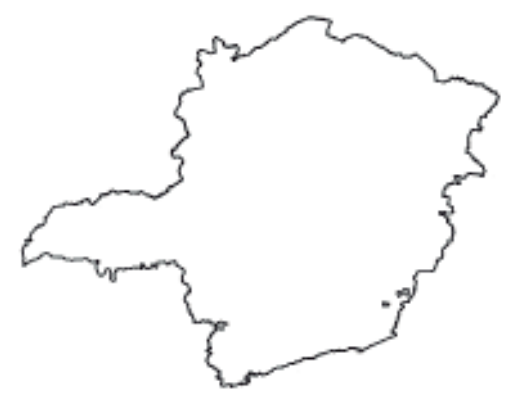

$0 \quad 150 \quad 300 \mathrm{~km}$

FIGURE 2 - Map of the Minas Gerais state. A counties with Pratylenchus spp. incidence. B counties with Rotylenchulus reniformis spp. incidence. $\mathbf{C}$ counties with Meloidogyne spp. incidence.

In the present study, the low population of Pratylenchus spp. observed in the samples may suggest the presence of some resistance factor in the cultivars evaluated.

Females of $R$. reniformes were observed in 47 samples, received from 15 counties in six coffee cultivars (Table 2), representing 1.94\% of the evaluated samples. Only one sample had a population density higher than 20 females of $R$. reniformes.

However, the presence of $R$. reniformes juveniles above 20 specimens per sample was observed in some cases. The reniform nematode ( $R$. reniformes) is frequently associated to coffee roots (CASTRO et al., 2008; BARROS et al., 2014). However, Kubo et al., (2009) demonstrated that eight coffee cultivars inoculated with a population of $R$. reniformes did not perform as suitable hosts for this nematode. However, in the present study a sample from cultivar Oeiras was observed with a high number of $R$. reniformes females. Studies concerning resistance of this cultivar against reniform nematodes are scarce.

The infested nurseries by Pratylenchus spp. and $R$. reniformis observed in this study were allowed to sell seedling to the coffee farmers. Dispersion of PPN in coffee areas occurs via propagation materials, agricultural tools and floods. However, the most efficient way for dissemination occurs via plant roots, especially seedlings of coffee or arboreal species used in the plantation. Therefore, is important that nurseries and public control agencies constantly inspect the phytosanitary quality of seedlings produced, especially concerning to the presence of PPN (CAMPOS; VILLAIN, 2005)

Regulatory Instruction IN 35 from MAPA determines the technical manager of the nursery as responsible for collecting seedlings samples. However, the number of incorrectly obtained samples received in the laboratories is substantial; in the majority of cases were samples with insufficient number of seedlings. This fact illustrates that care should be taken by the people responsible for sampling to fulfill the standards established by MAPA.

Samples analyzed represent more than 62 million coffee seedlings, $84 \%$ of them are traditional $C$. cultivars Catuaí and Mundo Novo (Table 3), which are susceptible to root-knot nematodes. Thus, proper care during sampling in the nurseries and commitment of surveillance institutions to avoid planting of infested seedlings are guaranties to avoid dissemination of PPN. Nevertheless, other PPN may be disseminated, once they are not included in the system of inspection by the surveillance institutions. 
TABLE 2 - Coffee cultivars associated with nematodes Meloidogyne spp., Pratylenchus spp. e Rotylenchulus reniformes.

Meloidogyne spp

Catuai vermelho IAC 44

Paraíso MGS 2

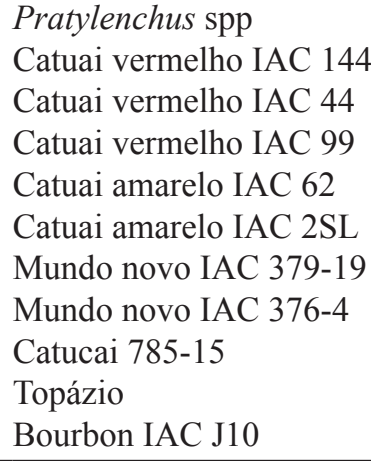

\author{
R. reniformis \\ Catuai vermelho IAC 144 \\ Catuai amarelo IAC 62 \\ Mundo novo IAC 379-19 \\ Mundo novo IAC 376-4 \\ Paraiso MG H 491-1 \\ Acauã
}

TABLE 3 - Total number of seedlings analyzed by cultivar

\begin{tabular}{|c|c|}
\hline Cultivars & Total seedlings \\
\hline Catuaí Vermelho IAC 144 & $17,757,302$ \\
\hline Catuaí Vermelho IAC 44 & $3,111,582$ \\
\hline Catuaí Vermelho IAC 99 & $7,309,370$ \\
\hline Catuaí amarelo IAC 62 & $9,666,624$ \\
\hline Catuaí amarelo IAC 39 & 95,200 \\
\hline Catuaí amarelo 24/137 & 283,500 \\
\hline Catuaí amarelo MULTILINEA F5 & 280,000 \\
\hline Catuaí amarelo 2015 & 90,000 \\
\hline Mundo Novo IAC 376-4 & $5,974,127$ \\
\hline Mundo Novo IAC 379-19 & $8,341,502$ \\
\hline Mundo Novo ACAIA & 25,000 \\
\hline Catucai 785-15 & $2,237,966$ \\
\hline Catucai amarelo 2SL & $2,430,951$ \\
\hline Catucai 24-137 & 142,179 \\
\hline Catucai vermelho MFS & 120,000 \\
\hline Oeiras MG6851 & 628,884 \\
\hline Bourbon amarelo IAC J9 & 167,791 \\
\hline Bourbon amarelo IAC J10 & 415,993 \\
\hline Acaia IAC 474/19 & $1,216,070$ \\
\hline Acaia do cerrado 1479 & 52,200 \\
\hline Topazio MG 1190 & $1,499,000$ \\
\hline Arara & 136,000 \\
\hline Icatu amarelo & 20,000 \\
\hline Acaua & 114,000 \\
\hline Acaua Novo & 40,000 \\
\hline MGS Paraiso 2 & 50,000 \\
\hline Paraiso MG H 419-1 & 19,457 \\
\hline Obatã IAC 1669-20 & 355,962 \\
\hline Catigua MG2 & 63,282 \\
\hline MGS ARANAS & 17,957 \\
\hline Catucaiam 24137 & 120,000 \\
\hline Total seedlings analyzed & $62,781,899$ \\
\hline
\end{tabular}

Coffee Science, Lavras, v. 13, n. 2, p. 178 - 186, apr./jun. 2018 


\section{CONCLUSION}

Coffee seedlings produced in Minas Gerais may disseminate PPN such as Pratylenchus spp. and Rotylenchulus reniformes, which are not targeted by the seedlings' surveillance system.

\section{ACKNOWLEDGEMENTS}

The authors gratefully acknowledge the Brazilian financial support provided by FAPEMIG, CAPES, CNPq, Instituto Nacional de Ciência e Tecnologia do Café INCT- Café, and Consórcio Pesquisa Café.

\section{REFERENCES}

BARBOSA, D. H. S. G. et al. Field estimates of coffee yield losses and damage threshold by Meloidogyne exigua. Nematologia Brasileira, Piracicaba, v. 28, n. 1, p. 49-54, jan/jun. 2004.

BARBOSA, D. H. S. G. et al. Survey of root-knot (Meloidogyne spp.) in coffee plantations in the state of Rio de Janeiro, Brazil. Nematologia Brasileira, Piracicaba, v. 28 , n. 1, p. 43-47, jan/ jun. 2004.

BARBOSA, D. H. S. G.; R. M. SOUZA.; H. D. VIEIRA. Field assessment of coffee (Coffea arabica L.) cultivars in Meloidogyne exigua- infested or -free fields in Rio de Janeiro State, Brazil. Crop Protection, Guildford, v. 29, n. 2, p. 175-177, Feb. 2010.

BARROS, A. F. et al. Root-knot nematodes, a growing problem for Conilon coffee in Espírito Santo state, Brazil. Crop Protection, Guildford, v. 55, p. 74-79, Jan. 2014.

BOISSEAU, M. et al. Resistance to Meloidogyne paranaensis in wild Coffea arabica. Tropical Plant Pathology, Brasília, v. 34, n. 1, p. 34:38-41, Jan./ Feb, 2009.

CAMPOS V. P.; VILLAIN, L. Nematode parasites of coffee and cocoa. In: LUC, M.; SIKORA, R. A.; BRIDGE, J. (Ed.). Plant-parasitic nematodes of tropical and subtropical agriculture, Wallingford: CABI, 2005, p. 529-579.

CARNEIRO, R. M. D. G. et al. Pathogenicity of Meloidogyne spp. (Tylenchida: Meloidogynidae) from Brazil and Central America on two genotypes of Coffea arabica.. Fitopatologia Brasileira (Impresso). Tropical Plant Pathology, Brasilia, v. 33, n. 4, p. 309-312, July/ Aug. 2008.
CASTRO J. M. C. et al. Levantamento de fitonematoides em cafezais do Sul de Minas Gerais. Nematologia Brasileira, Piracicaba, v. 32, n. 1, p. 5664, jan/mar. 2008.

CONAB. Acompanhamento da safra brasileira de café, safra 2016, dezembro/2016. Quarta estimativa. Disponível em: <http://www.conab.gov.br/OlalaCMS/ uploads/arquivos/16_12_27_16_26_51_boletim_cafe portugues_-4o lev_-_ez.pdf $>$. Acesso em 06 abr. 2016.

CONSÓRCIO PESQUISA CAFÉ. Disponível em: $<$ http://www.consorciopesquisacafe.com.br/index.php/ imprensa/noticias/753-2016-11-22-14-13-21>. Acesso em 06 abr. 2016.

FERRAZ, L. C. C. B. Brazil. In: SOUZA, R. M. (Ed.). Plant-Parasitic Nematodes of Coffee. Springer, 2008, p. 225-248.

GÖLDI, E. A. Relatório sobre a moléstia do cafeeiro na Província do Rio de Janeiro. Arquivos do Museu Nacional, Rio de Janeiro, p. 7-123, nov. 1887.

INOMOTO, M. M. et al. Pathogenicity of two Pratylenchus coffeae populations from Brazil on coffee plants. Nematology, Leiden, v. 9, n. 6, p. 853-858, 2007.

KUBO R. K.; FUZITA A.T.; OLIVEIRA C. M. G. Estudo do parasitismo do nematóide reniforme (Rotylenchulus reniformis) em oito genótipos de cafeeiros. In: VI SIMPÓSIO DE PESQUISA DOS CAFÉS DO BRASIL. 2009, Vitória. Resumos Expandidos... Brasília: Embrapa Café.

KUBO, R. K.; EULALIO, J.; OLIVEIRA, C. M. G. Consorciação e manejo de Brachiaria decumbens em mudas de cafeeiros infestados com Pratylenchus brachyurus em condições de casa de vegetação. Ciência Rural, Santa Maria, v. 45, n. 11, p. 1903-1909, nov. 2015

MOURA, R. M.; PEDROSA, E. M. R.; PRADO, M. D. C. Incidência de Pratylenchus cofeae causando severa nematose em cafeeiros no nordeste. Fitopatologia Brasileira, Brasília, v. 27, n. 06, p. 649, nov/dez. 2002.

MUNIZ, M. F. S. et al. Diversity of Meloidogyne exigua (Tylenchida; Meloidogynidae) populations from coffee and rubber tree. Nematology, Leiden, v. 10, n. 6, p. 897-910, 2008. 
PEREIRA, T. B. et al. Reação de genótipos de cafeeiro (Coffea arabica L.) a Meloidogyne exigua população Sul de Minas. Coffee Science, Lavras, v. 7, n. 1, p. 8490, jan/abr. 2012.

REZENDE, R. M. et al. Resistência de progênies de Coffea arabica em área infestada por Meloidogyne exigua. Nematropica, Bradenton, v. 43 n. 2, p. 233240, jul/dez. 2013.

SALGADO, S. M. L.; RESENDE, M. L. V.; CAMPOS, V. P. Reprodução de Meloidogyne exigua em cultivares de cafeeiros resistentes e suscetíveis. Fitopatologia Brasileira, Brasília v. 30, n. 4, p. 413415, jul/ago. 2005.

SALGADO, S. M. L. et al. Meloidogyne paranaensis e Meloidogyne exigua em Lavouras Cafeeiras da Região Sul de Minas Gerais. Coffee Science, Lavras, v. 10, n. 4, p. 475-481, out/ dez. 2015.
SANTOS, V. E. et al. Análise do setor de produção e processamento de café em Minas Gerais: uma abordagem matriz insumo-produto. Revista de Economia e Sociologia Rural, Piracicaba, v. 47, n. 02, p. 363-388, abr/jun. 2009.

SHIGUEOKA, L. H. et al. Reaction of Arabica coffee progenies derivative from Icatu to Meloidogyne paranaenses. Bragantia, Campinas, v. 75, n. 2, p. 193198, abr/jun. 2016.

TOMAZINI, M. D. et al. Resistência de genótipos de cafeeiros a Pratylenchus coffeae e Meloidogyne incognita. Nematologia Brasileira, Piracicaba, v. 29, n. 2, p. 193-198, jul/dez. 2005.

VILLAIN, L.; HERNÁNDEZ, A.; ANZUETO F. Central America. In: SOUZA, R. M. (Ed.). PlantParasitic Nematodes of Coffee. Springer, 2008, p. 261-276.

WIRYADIPUTRA, S.; TRAN, L. K. Indonesia and Vietnam. In: SOUZA, R. M. (Ed.). Plant-Parasitic Nematodes of Coffee. Springer, 2008, p. 277-292. 